\title{
An Experimental Examination of Activist Type and Effort on Brand Image and Purchase Intentions
}

\author{
Samuel H. Schmidt, Megan B. Shreffler, Marion E. Hambrick, and Brian S. Gordon
}

Samuel H. Schmidt, is an instructor in the Department of Health and Sport Sciences at the University of Louisville. His research interests include sport and social movements and athlete activism.

Megan B. Shreffler, PhD, is an assistant professor in the Department of Health and Sport Sciences at the University of Louisville. Her research interests include sport marketing and promotion and publicity.

Marion E. Hambrick, PhD, is an associate professor in the Department of Health and Sport Sciences at the University of Louisville. His research interests include social media usage in sports and diffusion of innovations in the sporting goods industry.

Brian S. Gordon, PhD, is an assistant professor in the Department of Health, Sport, and Exercise Sciences at the University of Kansas. His research interests include fan behavior/fan violence, marketing focusing on consumer behavior/psychology, and brand management.

\begin{abstract}
In 2016, several prominent athletes kneeled or sat during the national anthem of their games to protest social injustice in America. For their activism, these athletes inconsistently experienced both positive and negative consequences from their sponsors and fans. Therefore, the purpose of this study was to investigate this phenomenon more closely by examining the effect of activism type and activism effort on a sponsor's brand image and purchase intention of a product the athlete endorses, when controlling for brand familiarity. Participants $(N=384)$ were randomly assigned into groups in a 2 (activism type: safe, risky) x 2 (activism effort: low, high) experimental study. Results indicated brand image and purchase intention were negatively impacted by risky activism compared to safe activism, but activism effort had no effect on the two variables. Further implications and future research are expanded upon in the discussion.
\end{abstract}

Keywords: athlete activism, brand image, purchase intention, activism type, activism effort

On August 26, 2016, San Francisco 49ers quarterback Colin Kaepernick sat on the bench during the United States national anthem of a National Football League (NFL) preseason game (Clayton, 2016). After the game, Kaepernick spoke to the media proclaiming he refused to "stand up to show pride in a flag for a country that oppresses Black people and people of color" (Clayton, 2016, para. 3). Despite rhetoric claiming Kaepernick was anti-patriotic, Kaepernick reiterated his desire to sit stemmed from the racial injustices in America. Since the preseason, no less than 13 NFL players joined Kaepernick in protesting Black oppression during the U.S. national anthem (Breech, 2016). Brandon Marshall, linebacker for the Denver Broncos, joined Kaepernick in his protests by kneeling during the national anthem of the first NFL regular season game (Villanueva, 2016).
Both Kaepernick and Marshall experienced negative and positive consequences for engaging in racially sensitive activism. Kaepernick received immense backlash from NFL players (Schilken, 2016), NFL executives (Robinson, 2016), Republican Presidential Candidate Donald Trump (Wilder, 2016), and San Francisco fans, who burned his jersey (Pleasance, 2016). Marshall also received backlash for kneeling, but in the form of a financial loss. Air Academy Federal Credit Union and CenturyLink, two organizations that sponsored Marshall, terminated their endorsement agreements with the linebacker (Garcia \& Dotson, 2016). Despite the backlash, Kaepernick and Marshall received benefits due to their actions. On September 6, 2016, Kaepernick led the NFL in jersey sales (Heitner, 2016). Additionally, Marshall signed an endorsement deal 
with RushCard, owned by music mogul Russell Simmons (Crabtree, 2016). The aforementioned negative and positive consequences indicate inconsistent results for athletes engaging in racial activism.

The consequences for Kaepernick and Marshall's activism could stem from more than just the issue they are protesting. As noted, Kaepernick and Marshall received immense backlash for engaging in physical activism. Shortly before Kaepernick's activism, Carmelo Anthony posted to social media about the racial divide in America. He was celebrated for his activism as he called on prominent athletes to use their status for activism in support of Black lives (O'Donnell, 2016). The two demonstrations were about the same social issue, but the activism engagement differed. Kaepernick endured a tremendous amount of criticism by sitting during the national anthem, making many in the nation uncomfortable with his actions, while Anthony received praise for a social media post on the same issue. The aforementioned cases indicate the way in which the message is delivered may have an impact on the consequences of the activism for the player and accompanying organizations.

The stories from the athletes above highlight a need to examine athlete activism in more detail based on varying responses, whether positive or negative. The impact of athlete endorsement on sponsor brand image has been studied previously (Gwinner \& Eaton, 1999; Seno \& Lukas, 2007). However, while scholars have examined the impact of the individual athlete brand on sport brand image (Cunningham \& Regan, 2012) and even looked at the role of athlete transgressions (Lohneiss \& Hill, 2014), the impact of athlete activism on sponsor brand image has escaped empirical examination. Further, given what is known about the impact of an athlete endorser on a sponsor's brand, understanding the potential negative consequences of Kaepernick and Marshall's activism is important since it is unknown if this represents a unique event or a sign of events to come for athlete activists engaging in potentially risky forms of activism. Additionally, the effort an athlete gives towards his or her activism, whether kneeling during an anthem, posting to social media, or other actions, could be an important factor. As mentioned, Kaepernick and Anthony spoke on the same issue, but were treated differently by society. Perhaps the content of the message is less important than the medium through which the message is delivered. Therefore, the purpose of this study was to investigate the effect activism effort and activism type had on a sponsor's brand image and purchase intention of a product the athlete endorses, when controlling for brand familiarity.

\section{Literature Review}

\section{Athlete Activism}

General activism is defined as "extra-ordinary, extra-usual practices which aim, collectively or individually, institutionally or informally, to cause social change" (Bayat, 2005, p. 893-894). Focusing on sport, Kaufman and Wolff (2010) interviewed athlete activists who use sport to promote progressive social change. Aygemang, Singer, and DeLorme (2010) coined political activism as "organized and collective forms of protest and conflict" (p. 420) in their study of Black college athletes' perceptions of activism. Based on previous literature of general activism and sport literature focusing on athlete activists, the definition for athlete activism used for this study was an amateur or professional athlete's practices that aim, collectively or individually, institutionally or informally, to promote progressive social change (Presley, Shreffler, Hancock, \& Schmidt, 2016).

Kaufman and Wolff (2010) provided some of the first literature on athlete activism in their investigation of the links between activism and sport. After interviewing several athlete activists, the researchers identified four main dimensions sport fosters in athlete activists: social consciousness, meritocracy, responsible citizenship, and interdependence. Athlete activists are socially conscious, meaning they have an awareness of the surrounding structural reality and an ability to positively impact the lives of others utilizing their platform. Meritocracy is the belief that trying hard, doing good deeds, and being talented will lead to happiness and prosperity. Athletes see meritocracy every day in athletics, one of the only places meritocracy exists, and question why the construct cannot be applied outside sport. Athlete activists also believe they need to be responsible citizens. Responsible citizenship off the field is akin to good sportsmanship on the field, one of the first lessons in athletics. Finally, interdependence is the athletes' recognition that they could not succeed without the help of others and their help may be needed to help others succeed. The athletes also noted engaging in sport shared many of the same characteristics as working for social change.

Despite the links between activism and athletics, negative perceptions for athlete activism surround athletes. Agyemang, Singer, \& DeLorme (2010) noted Black athletes believed race and racism remain an issue in athletics. The athletes recognized the deeds from Muhammad Ali, John Carlos, and Tommy Smith, but were unwilling to engage in activism in today's society. The athletes were unwilling to engage in controversial forms of activism for perhaps a number 
of different reasons. It is known that athletes engaging in activism risk backlash from the media, coaches, teammates, and their fans (Kaufman, 2008), as well as the financial backlash from a loss of a sponsor or team contract (Agyemang et al., 2010). In the case of Black athletes, specifically, the lack of activism from one of the most influential athletes of all time, Michael Jordan, may have discouraged recent athlete activism (Agyemang, 2011).

\section{Activism Type}

In their investigation of activism risk, Cunningham and Regan (2012) noted financial backlash in the form of endorser fit might not be impacted by controversial forms of activism. Their study explored athlete activism's effect on endorser fit between activism type of an athlete and a sport organization and sport product. The researchers investigated activism related to a controversial issue (Anti-War) and well-received activism (Anti-Childhood Obesity) using experimental design with hypothetical scenarios. Their findings indicated no difference between the controversial activism and well-received activism on the trustworthiness of the athlete and endorser fit. The findings countered the perceptions current Black athletes have about the risks of engaging in activism by noting athletes engaging in potentially controversial forms of activism did not negatively impact consumer perceptions about the organization or product.

\section{Activism Effort}

Athletes utilize a large spectrum of effort levels for their activism (Sanderson, Frederick, \& Stocz, 2016; Schmittel \& Sanderson, 2015). Towards the high end of the effort of activism spectrum lie physical acts of protests or attempts for change, like Kaepernick's demonstration. In 2014, five Black NFL players for the St. Louis Rams held their hands in up a "hands up, don't shoot" pose during their pre-game introductions. Their protest symbolized the pose utilized by protestors in Ferguson, Missouri because of Michael Brown's death. For their physical activism before the NFL game, the athletes were subjected to racial abuse (Sanderson et al., 2016). The St. Louis Rams organization also received negative consequences as fans were organizing Facebook groups and hashtags to boycott the Rams organization. Clearly, the physical activism and message of the players combined to have a detrimental impact on the St. Louis Rams organization.

On the low end of the activism effort spectrum is slacktivism, a type of activism NFL players engaged in during the Trayvon Martin case in 2014 (Schmittel \& Sanderson, 2015). Slacktivism equates to lazy activism, such as posting on social media (Lim, 2013). This type of activism has garnered backlash as slacktivism can be seen as a token effort to enhance the perception of kindness and selflessness in the individual performing the slacktivism without sufficient cost or effort from the activist (Christensen, 2012; Kristofferson, White, \& Peloza, 2014; Lim, 2013). Additionally, Lim (2013) noted slacktivism could backfire if the message represents non mainstream or risky ideologies.

\section{Celebrity Endorsement}

Extensive research has been conducted on celebrity endorsement (see Erdogan, 1999). Organizations use celebrity endorsements as a means to drive favorable attitudes towards products or events. For instance, Silvera and Austad (2004) noted positive attitudes towards endorsers and inferences towards endorsers predict attitude towards products. Simply put, the more favorable view of the endorser, the more favorable view of the product. Within sport, a large portion of this celebrity endorsement research has identified what qualities or characteristics lead to predicting effectiveness of celebrity endorsements (Cunningham \& Bright, 2012; Cunningham \& Regan, 2012; Cunningham, Fink, \& Kenix, 2007; Fink, Cunningham, \& Kensicki, 2004; Kamins, 1990; Kim \& Na, 2007; Lohneiss \& Hill, 2014; Ohanian, 1990). Multiple characteristics that may impact effectiveness of a message include source attractiveness, match-up hypothesis (celebrity-product congruence), and source credibility (Kim \& Na, 2007). Kamins (1990), through match-up hypothesis, proposed endorsers are more effective when there is a relationship between the product and the endorser. In addition, Ohanian (1990) argued expertise can impact purchase decision more than any other factor. Fink and colleagues (2004), in their empirical study, acknowledged expert knowledge might trump attractiveness, as they found in the case of an expert softball player and an attractive softball player promoting an event and future purchase intentions. Hence, one of the main factors in generating positive views (such as brand image and purchase intention) is the association between the product and the endorser. Additionally, the expert knowledge of the athlete towards the product can also generate positive views. Empirical studies have also shown athlete celebrity endorsement can be reliably tested with brand image (Lohneiss \& Hill, 2014) and purchase intentions (Cunningham et al., 2007; Cunningham \& Regan, 2012; Fink et al., 2004).

\section{Brand Image}

Brand image is defined as the "perceptions about a brand as reflected by the brand associations held in consumer memory" (Keller, 1993, p. 3). According 
to his framework, Keller posits brand image is determined by a set of linkages a consumer holds from his or her memory to a particular brand, otherwise known as brand associations. Specifically, these associations may comprise strong, favorable, and unique beliefs concerning the brand (Biehal \& Sheinin, 2007). Further, from a controllability standpoint, brand image is more malleable when compared to other uncontrollable elements, such as team performance and the results of sport contests (Bauer, Stokburger-Sauer, \& Exler, 2008). Bauer et al. (2008) contend that these associations should not be overlooked since they are not only capable of affecting consumer beliefs about the product, but they are also instrumental in influencing consumer behavior and engagement. Among elements that can impact the perception of an overall sport team brand image, athletes are consistently recognized as one of the strongest and most unique associations (Bauer et al., 2008; Gladden \& Funk, 2001; Ross, James, \& Vargas, 2006).

McCracken (1989) noted a celebrity endorsement, like one from a successful athlete, transfers its image onto a brand when the two are paired. Organizations utilize this transference of image with a celebrity to build, strengthen, or alter their brand image through sponsorship agreements (Gwinner \& Eaton, 1999; Seno \& Lukas, 2007). From the product's perspective, Del Rio, Vázquez, and Iglesias (2001) noted a positive brand image, specifically for athletic shoes, led to a consumer's willingness to pay a premium price for the brand, willingness to accept a brand extension, and willingness to recommend a brand. Additionally, a stronger brand image may help organizations increase their fans' loyalty and consumption behaviors (Bauer et al., 2008). However, if consumers perceive the athlete endorser in a negative light, brand image is likely negatively affected (Lohneiss \& Hill, 2014).

\section{Purchase Intentions}

While brand image investigates the perception of a brand, purchase behavior investigates the behavioral action of the participant. Spears and Singh (2004) defined purchase intentions as an "individual's conscious plan to make an effort to purchase a brand" (p. 56). Purchase intention, while not necessarily a predictor of actual purchase behavior, is an expected indicator of an individual's motivation to purchase the specific product/service (Dees, Bennett, \& Villegas, 2008). This is important for sport organizations as purchase intentions can be a useful indicator of future sales (Crompton, 2004). The belief stems from Ajzen's (1985) Theory of Planned Behavior as purchase intention moderated the relationship between attitude and behavior. If consumers highly regard the endorser, the desire to purchase may increase in the consumer's mind. Goldsmith, Lafferty, and Newell (2000) noted organizations can use high endorser credibility to build the purchase intent of their products. Negative information surrounding an athlete endorser, however, could hurt the purchase intention of an organization the athlete is endorsing (Lohneiss \& Hill, 2014; Murray $\&$ Price, 2012). Therefore, measuring the purchase intention of an activist athlete has a profound impact on the organization because intention to purchase stems from favorable perceptions of products and services, whereas a less favorable intent to purchase could decrease actual purchase behavior for an organization (Spears \& Singh, 2004).

\section{Hypothesis Development}

The current study's aim was to investigate the impact of athlete activism type and effort on a sponsor's brand image and purchase intention of a product, when controlling for brand familiarity. The researchers utilized an experimental design to satisfy the purpose of the study. Hypotheses were developed to test the experiment. These hypotheses were developed from past literature, with a focus on studies utilizing athlete activists.

Negative perceptions of athlete endorsers can hurt the brand image of an organization and purchase intention of a product (Lohneiss \& Hill, 2014). However, Cunningham and Regan (2012) specifically studied an athlete's engagement with risky and safe activism. They found no statistical difference between risky and safe activism on perceptions between the athlete and the organization the athlete was endorsing. Therefore, the following hypotheses were derived:

\section{H1: There will be no statistical difference in perception between risky activism and safe activism on brand image of a sponsor, when controlling for brand familiarity.}

\section{H2: There will be no statistical difference in perception between risky activism and safe activism on purchase intention of a sponsor's product, when controlling for brand familiarity.}

With a focus on activism effort, literature has shown backlash for athletes engaging in high effort (i.e., physical protests; Sanderson et al., 2016) and low effort (i.e., slacktivism; Lim, 2013). For this reason, the following hypotheses were also derived:

\section{H3: There will be no statistical difference in perception between high effort activism and low effort activism}


on brand image of a sponsor, when controlling for brand familiarity.

H4: There will be no statistical difference in perception between high effort activism and low effort activism on purchase intention of a sponsor's product, when controlling for brand familiarity.

\section{Method}

\section{Sample}

Participants were recruited from Amazon's Mechanical Turk (M-Turk), an "online labor market where requesters post jobs and workers choose which jobs to do for pay" (Mason \& Suri, 2012, p. 1). Despite M-Turk being relatively new for behavioral research, researchers have legitimized its use for psychology and other social sciences (Buhrmester, Kwang, \& Goslin, 2011). Specifically, Buhrmester et al. (2011) noted M-Turk users were more demographically diverse than standard Internet and American college samples, and the data obtained was at least as reliable as data obtained via traditional methods. Additionally, M-Turk allows the researcher to only request "M-Turk Masters," an elite group of workers who have demonstrated a proficient history of accuracy for M-Turk jobs. The researchers in this study enabled this selection in order to increase the validity of the sample. M-Turk Masters workers received $\$ 0.25-0.40$ (U.S. Dollars) for participation in and completion of the survey.

Initially, 384 individuals participated in the study. A total of 305 participants remained in the study after eliminating 43 surveys that were not completed and 36 for failing to answer the captcha survey item correctly. The participants were mostly Caucasian/White $(n=$ $181)$, while others were Asian $(n=65)$, African American/Black $(n=30)$, Hispanic $(n=223)$, and Native Indian/Alaska Native $(n=6)$. The sample was also mostly male $(n=186)$ with an average age of 36.85 years $(S D=10.40)$, ranging in age from 19 to 72 .

\section{Procedures}

Before initiating the actual experiment, the researchers conducted two pilot focus groups. Responses from these groups helped to determine (a) what constitutes high and low effort activism, (b) what constitutes risky versus safe social issues for an athlete to engage in, and (c) a typical product and accompanying organization an athlete would endorse. The main study incorporated these findings. The focus groups derived from a convenience sample of college students from a large Southern metropolitan university. The students were part of a class focusing on issues and ethics in sport.
This class was specifically selected as the students were aware of major societal trends in sport. The total focus group sample included three Black females, six Black males, two White females, and three White males. The students' class ranged from freshmen to juniors, with a mean age of $20.07(S D=0.62)$. The groups were separated into two representative groups of seven to allow for more opinions from the participants (Creswell, 2014). The pilot focus groups lasted roughly 20 minutes each and were recorded for playback. The researchers came together to interpret the results of the focus groups. Based on the frequency of the focus group responses, the following were included in the main study: (a) high effort level of activism-creating an organization, (b) low effort level of activism-posting on social media, (c) risky social issue for an athlete to engage in-racial equality, (d) safe social issue for an athlete to engage in-anti-childhood obesity, and (e) an athlete product endorsement-a Nike athletic shoe.

After the data from the focus groups were collected and incorporated into the final survey instrument (Appendix A), the instrument was uploaded to Amazon M-Turk. From September 27, 2016 to November 17,2016 , respondents took part in the study. Once the participants completed the study, they were given an alpha-numeric code to enter so the researchers would know the individual completed the survey and could eliminate any response without the proper code. The main survey instrument consisted of three sections: introduction and covariate response, experimental manipulation, and final measures. Participants received a letter informing them of the study's purpose, benefits, risks, Internal Review Board approval evidence, contact information for the investigators, and consent to participate in the study. After reading and agreeing to the consent form, participants were asked about their brand familiarity for the organization, Nike. Brand familiarity was used as the covariate for the final analysis.

After the initial page, the participants moved onto the next page and were greeted by the following introductory paragraph:

In attempting to strengthen the brand image of its high performance athletic shoe, Nike is seeking to add a new spokesperson. To do so, it has gathered information on a nationally recognized track and field athlete. This includes his accomplishments, personal information, and the community engagement in which the athlete is involved. Please review the material provided on the following pages and, after doing so, provide your assessment of your attitudes towards Nike. (Appendix A) 
Information on the athlete was given on the same page, including a fictitious athlete's name (Charles Smith), sport (Track and Field), event (800m distance), and accomplishments (1st place: 2016 NCAA Outdoor $800 \mathrm{~m}$, 3rd place: 2016 USA Outdoor Championships, 5th place: 2015 World Outdoor Championships, and three time NCAA All-American). The researchers' use of an introductory paragraph and biography of the athlete was similar to the introductory paragraph and biography utilized in Cunningham and Regan's (2012) study.

On the next page, the participants received the experimental manipulation with the following statement: "Nike is also taking into consideration Charles Smith's community engagement activities. Please review the below information on Smith's community engagement." As per Cunningham and Regan (2012), this study used community engagement as a synonym for activism. Every participant next received one of the following statements which outlined the community engagement for Charles Smith.

The statement representing low effort/risky activism read, "Charles Smith spends time occasionally posting tweets about Black Lives Matter. This is an organization with the primary aim of advancing the understanding of the causes, consequences, and prevention of racial inequality."

The statement representing high effort/risky activism read, "Charles Smith created a regional chapter for Black Lives Matter. This is an organization with the primary aim of advancing the understanding of the causes, consequences, and prevention of racial inequality."

The statement indicating low effort/safe activism read, "Charles Smith spends time occasionally posting tweets about Healthy Kids Community. This is an organization with the primary aim of advancing the understanding of the causes, consequences, and prevention of childhood obesity."

The statement for high effort/safe activism read, "Charles Smith created a regional chapter for Healthy Kids Community. This is an organization with the primary aim of advancing the understanding of the causes, consequences, and prevention of childhood obesity."

Of note, Black Lives Matter and Healthy Kids Community are actual organizations. The researchers specifically utilized real organizations to provide context for the athlete's community engagement.

Next, participants responded to a series of survey items. The questionnaire included the following measures: brand image of Nike with Charles Smith as an endorser, purchase intention of Nike with Charles
Smith as an endorser, a captcha question, and two manipulation checks. The items addressing brand image and purchase intention of Nike with Charles Smith endorsing determined the effect Smith's activism effort and social issue had on the participants' perceptions of Nike. The survey instrument included the captcha question, "Please select somewhat disagree," to ensure participants paid attention to questions and did not select one answer to get through the survey. Mason and Suri (2012) strongly suggested using captcha questions when conducting behavior research on M-Turk. Those who failed to select strongly disagree from the captcha question were dropped from the study to ensure high quality responses. The survey instrument also included two manipulation checks to ensure the effort level and level of risk of the activism effort were appropriate. Finally, the study concluded with demographic items assessing race, age, and gender.

\section{Measures}

The experiment asked participants to respond to various measures including brand familiarity, brand image, and purchase intention. The mean scores were used for the final score for all variables. For instance, brand familiarity's mean score was calculated to provide a brand familiarity total score for each participant. The same method was used for brand image and purchase intention.

Brand familiarity. Brand familiarity of Nike served as a covariate for the study. Brand familiarity is the consumer's level of direct and indirect experience with a product (Alba \& Hutchinson, 1987). In theory, individuals who are less familiar with a brand will have a greater range of attitudes and purchase intentions than those who are more familiar with a brand (Carrillat, Lafferty, \& Harris, 2005). An individual who is less familiar with Nike could have a more volatile response to the athlete's activism than an individual who is more familiar with Nike and their products. Thus, brand familiarity was used as a control variable to minimize its impact on the measured outcomes and similarly used by the study performed by Lohneiss and Hill (2014). Brand familiarity of the organization was measured using a three-item, seven-point semantic differential scale. Participants were asked to respond to their views of Nike as an organization. The response anchors included: Familiar/Unfamiliar, Inexperienced/Experienced, and Knowledgeable/Not Knowledgeable (Kent \& Allen, 1994). The items received a Cronbach's alpha of $\alpha=0.85$ in 1994 (Kent \& Allen) and more recently a score of $\alpha=0.71$ (Lohneiss \& Hill, 2014). The current study yielded a Cronbach's alpha score of $\alpha=0.87$. 
Brand image. Brand image of Nike with Charles Smith endorsing the product was the first dependent variable for the current study. The construct was a modified version created by Martínez and Pina (2009). The authors reported a Cronbach's alpha of $\alpha$ $=0.85$. The items were slightly modified for this study to read: "Nike endorsed by Charles Smith is a brand that is of high quality," "Nike's products endorsed by Charles Smith have better characteristics than that of the competitors," "Products of competitors are usually cheaper than Nike's products endorsed by Charles Smith," "Nike endorsed by Charles Smith is a nice brand," "Nike endorsed by Charles Smith has a personality that distinguishes itself from its competitors," "Nike endorsed by Charles Smith is a brand that does not disappoint its customers," "Nike endorsed by Charles Smith is one of the best brands in the sector," and "Nike endorsed by Charles Smith is very consolidated in the market." The items were measured using a 7-point Likert scale from strongly disagree to strongly agree. The scores combined to create an average score of the brand image of Nike. The current study yielded a Cronbach's alpha score of $\alpha=0.94$.

Purchase Intention. Purchase intention was the second dependent variable in the current study. The items were slightly modified from the purchase intention scale used by Kwon, Trail, and James (2007). The authors originally reported a Cronbach's alpha score of $\alpha=0.93$. Purchase intention was used in this study to measure the effect of the athlete activist endorser. The items read: "I would purchase Nike athletic shoes endorsed by Charles Smith," "I would consider buying Nike athletic shoes endorsed by Charles Smith," and "The probability that I would consider buying Nike shoes endorsed by Charles Smith is high.” The Cronbach's alpha score for purchase intention was $\alpha=0.98$.

\section{Data Analysis}

An analysis of variance (ANOVA) was utilized to determine the adequacy of the manipulations before examining the hypotheses. The manipulation checks ensured groups that received risky/safe or high effort/ low effort believed their activism's appropriate level of risk and effort. Hypothesis 1-4 were tested using a 2 (activism type: risky and safe) x 2 (activism effort: high and low) multivariate analysis of covariance (MANCOVA). The independent variables were the activism type (safe and risky) and activism effort (low and high). The dependent variables were brand image and purchase intention for the organization Nike with Charles Smith endorsing Nike athletic shoes. Brand familiarity served as the control.

\section{Results}

\section{Sample and Group Breakdown}

The number of participants split relatively evenly between the four groups: low effort/safe activism ( $n=82)$, high effort/risky activism $(n=78)$, low effort/ risky activism $(n=76)$, and high effort/safe activism $(n=69)$. The total mean for brand familiarity was 6.17 $(S D=1.01)$. Brand familiarity means per group were broken down further into low effort/safe activism $(M=6.28, S D=0.790)$, high effort/risky activism $(M=6.11, S D=1.20)$, low effort/risky activism $(M=6.14, S D=1.01)$, and high effort/safe activism $(M=6.15, S D=1.04)$.

\section{Manipulation Checks}

The survey instrument included several manipulation checks to ensure the manipulation measured low versus high effort and safe versus risky activism. To ensure participants had the correct perception of safe and risky activism, each individual was presented with the following statement, "people generally support the cause for which the athlete volunteers his time." The statement was similarly utilized by Cunningham and Regan (2012). Participants were asked to respond on a seven-point Likert scale ranging from strongly disagree (1) to strongly agree (7). The results of the ANOVA revealed a statistically significant difference between the group that received the risky activism surveys and those receiving the safe activism surveys $F(1,303)=$ $83.019, p<.000$. Respondents viewed safe activism $(M=5.85, S D=0.922)$ as more favorable than risky activism $(M=4.40, S D=1.73)$.

Similarly, a manipulation check was used to determine if a difference existed between high level and low level efforts of activism. The statement read, "the athlete gave a high level of effort towards his social cause." Once again, a seven-point Likert scale ranging from one (strongly disagree) to seven (strongly agree) was utilized. Another ANOVA was conducted to determine whether a statistical difference existed between the two means. The ANOVA revealed a statistical difference between high and low effort $F(1,301)=28.974, p<.000$. Respondents viewed high effort $(M=5.50, S D=1.47)$ as more intense than low effort $(M=4.45, S D=1.87)$. Thus, participants perceived risky activism to have more risk than safe activism for the athlete and high effort as more intense than low effort activism for the athlete.

\section{Research Hypotheses}

The mean scores and standard deviations for the variables of the interest can be found in Figure 1 and Figure 2. 


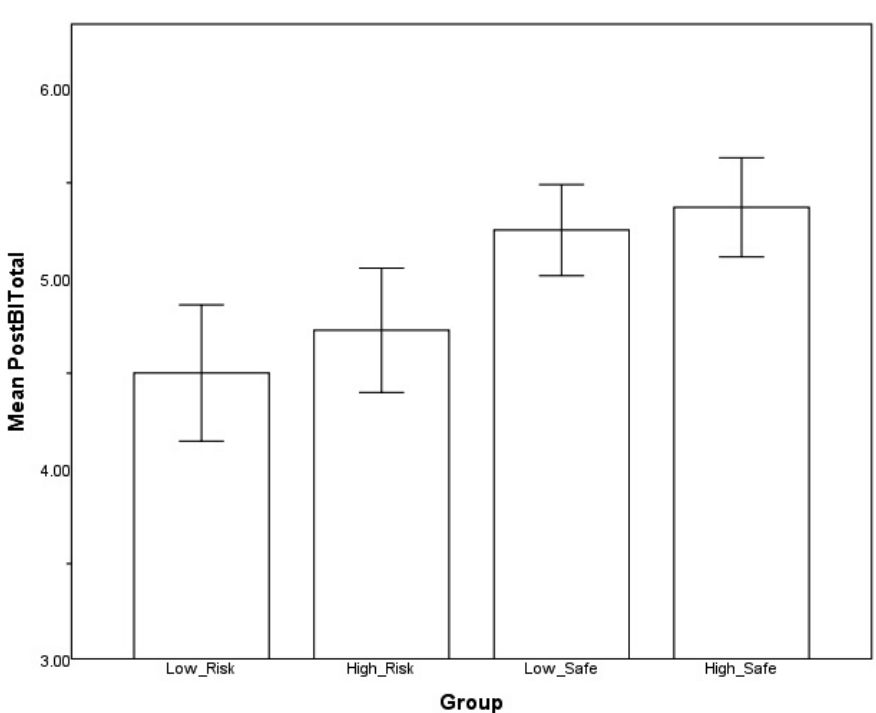

FIGURE 1. Descriptive statistics for brand image Scale endpoints $=1,7$

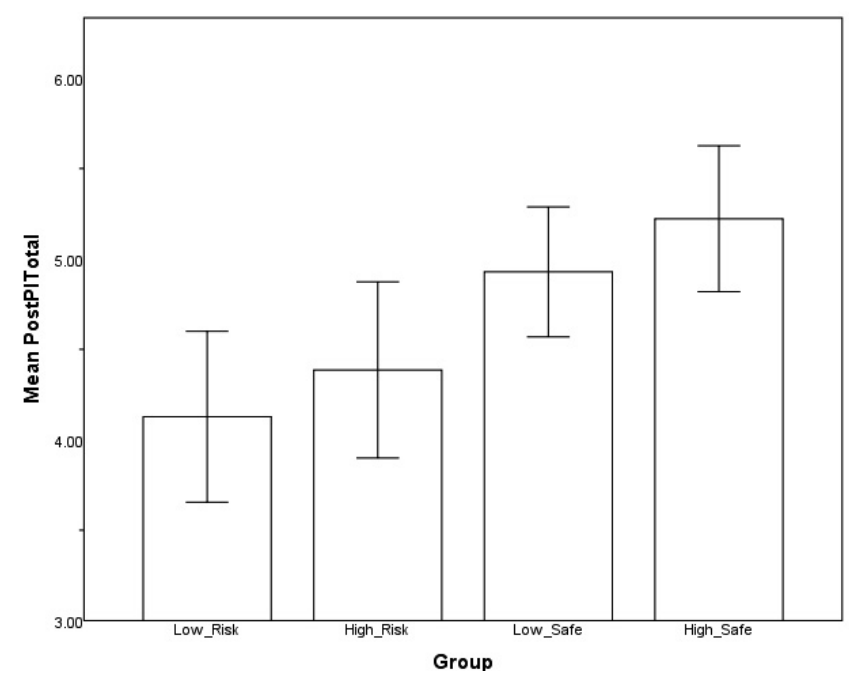

FIGURE 2. Descriptive statistics for purchase intention Scale endpoints $=1,7$

TABLE 1. Results of the MANCOVA.

\begin{tabular}{l|c|c|c|c}
\hline \multicolumn{1}{c|}{ Effect } & Pillai's Trace & F & Sig. & $\eta 2$ \\
\hline Brand Familiarity & .104 & 16.307 & $.000^{*}$ & .104 \\
\hline Effort (High/Low) & .006 & .827 & .438 & .006 \\
\hline Type (Risky/Safe) & .067 & 10.034 & $.000^{\star}$ & .067 \\
\hline Effort x Risk & .003 & .419 & .658 & .003 \\
\hline
\end{tabular}

${ }^{*}$ Denotes significant relationship at the .05 level

A $2 \times 2$ MANCOVA was conducted with brand familiarity as the covariate, group (low/risk, high/risk, low/safe, and high/safe) as the independent variable, and brand image and purchase intention as the dependent variables. The interaction effect between the level of risk and the level of effort was non significant $[F(2,281)=0.419, p>.05$; See Table 1].

There was a main effect for level of risk $[F(2,281)=$ $10.03, p<.05, \eta 2=.067]$. Further analysis indicated safe activism $(M=5.30, S D=0.109)$ yielded a higher brand image score than risky activism $(M=4.62$, $S D=0.105)$. Therefore, $\mathrm{H} 1$, indicating that level of risk would have no effect on brand image, was rejected. Additionally, purchase intention of the product was higher in safe activism $(M=5.01, S D=0.154)$ than in risky activism $(M=4.29, S D=0.149)$. $\mathrm{H} 2$, which suggested there would be no difference in level of risk on purchase intention, was also rejected. There was no significant main effect for level of effort $[F(2,281)$ $=0.4827, p>.05]$. Thus, the authors failed to reject $\mathrm{H} 3$ and $\mathrm{H} 4$ (there was no significant difference between level of effort on brand image and purchase intention, respectively).

\section{Discussion}

Athletes such as Colin Kaepernick, Brandon Marshall, and Carmelo Anthony, to name a few, utilized their platform as sport celebrities for activism in 2016. Their messages differed on topic and intensity, but all had consequences. For Kaepernick and Marshall, their activism brought public backlash and a loss of sponsors for their physical acts of defiance against racial oppression. Carmelo Anthony, on the other hand, was celebrated for his Instagram post about the same issue. As athlete endorsement deals reach enormous heights (Weber, 2016), organizations should be wary of the impact an athlete engaging in activism could pose on their brand image and product's purchase intention. Therefore, the purpose of this study was to 
investigate the effect activism type (risky and safe) and activism effort (high and low) had on a sponsor's brand image and purchase intention of a product the athlete endorses, when controlling for brand familiarity through an experimental design. While the results indicated activism effort did not impact brand image and purchase intention, activism type did have an impact on the same variables. An athlete engaging in risky activism is more likely to negatively impact an organization's brand image and product's purchase intention, when compared to an athlete engaging in safe activism.

The results of the study indicated no statistical interaction effect between effort and risk. Despite no statistical difference, the means for brand image and purchase intention were the most favorable for high effort and safe activism and were the least favorable for low effort and risky activism (See Figures 1 and 2). Additionally, there was no statistical difference between high and low activism effort. To the participants, brand image and purchase intention were not affected by an athlete's occasional tweet or by the athlete creating a regional chapter for his activism. Sanderson et al. (2016) noted a tremendous amount of backlash for the St. Louis Rams when a few of their players performed physical activism against racial injustice. The results of this study note that racial injustice may make more of an impact than the medium in which the athlete activists use to perform their activism. Thus, athletes who wish to engage in activism through social media to control the message (Schmittel \& Sanderson, 2014) should understand their activism effort is not viewed differently from someone engaging in a high-level effort activism, per this study's results.

The results also indicated a statistical difference between risky and safe activism types. The participants who had the safe activism manipulation (anti-childhood obesity) viewed Nike in a more favorable light in terms of brand image and purchase intention than the risky activism (racial equality). While this does not directly contradict the study performed by Cunningham and Regan (2012), who noted no difference between safe and risky activism type in endorser fit, it provides inconsistent results surrounding the impact potentially risky athlete activism has on the athlete and representative organization. Perhaps the appropriateness of the activist athlete and the endorsement is not in question, but the actual representation of the organization when the athlete is an endorser. The results could potentially confirm an athlete's fear of financial backlash for speaking out against a social injustice (Agyemang et al., 2010). If organizations were to understand that their athlete was engaging in risky forms of activism, it could hurt their brand image and purchase intention of a product the athlete endorses. This, in turn, may prevent the organization from using the athlete as a representative in the first place, thus limiting an athlete's earning potential.

While it is important to note the statistical difference between safe and risky activism type, the means between the two are both favorable. Despite risky activism having a more detrimental impact on brand image than safe activism, both reflected at least a slightly favorable view of the brand image for Nike. The same can be seen in purchase intention of a Nike shoe. Therefore, despite the decrease in brand image of Nike and purchase intention of Nike athletic shoes when risky activism is involved rather than safe activism, both outcomes are still favorable for Nike. Similar findings can be found in Lohneiss and Hill (2014), who investigated the impact Tiger Woods' transgressions had on the brand image of Nike. The researchers noted a decrease in the brand image of Nike when Tiger Woods' transgressions were acknowledged, but the views of Nike were still favorable when comparing Tiger Woods' endorsing Nike and Woods not endorsing Nike. In other words, respondents may be willing to discount negative information about the athlete when evaluating the brand image of the organization (Lohneiss \& Hill, 2014). Therefore, there is potential for the organization to actually benefit from the activism, even if there is less benefit derived from the risky activism, compared to the safe activism.

\section{Conclusion}

There are numerous implications that can be drawn from this study. First, and most obvious, is the decrease in brand image of Nike and purchase intention of Nike products from an athlete who engages in risky activism as opposed to safe activism. Athletes' fear of financial backlash from sponsors or teams (Agyemang et al., 2010) may be warranted. This finding may provide another reason for athletes to not engage in particularly risky forms of activism (Kaufman, 2008; Kaufman \& Wolff, 2010; Sanderson et al., 2016). From the sport manager standpoint, an organization should be cautious when building a relationship with an athlete who may be involved in particularly risky forms of activism.

Another implication from this study is derived from the lack of a statistical difference between high and low effort towards activism. Athletes wishing to engage in activism should take solace in knowing the brand image of the organization and purchase intention of a product the athlete represents may not be hindered based on if the athlete is tweeting about the social 
cause or creating a regional chapter. Thus, whether athletes decide to use social media for their activism (Schmittel \& Sanderson, 2014) or perform physical activism (Sanderson et al., 2016), there is no difference on brand image and purchase intention between the two types of activism.

A third implication derives from the combination of risk and effort on the means for brand image and purchase intention. The high effort/safe athlete was viewed as the most positive for both dependent variables, while the low effort/risky athlete was the least positive. This finding is supported by Cunningham and Regan (2012), who noted activism type does predict perceptions of athlete trustworthiness. Perhaps activism effort also leads individuals to question the trustworthiness of athletes. When engaging in activism, sponsors would be better suited finding an athlete who will engage in safe activism in a high effort way. For instance, Cam Newton, NFL quarterback for the Carolina Panthers, has received praise for volunteering at elementary schools and donating money for children to buy Christmas presents for themselves and their parents (McManus, 2015).

As with any study, there are several limitations present. First, the use of a hypothetical athlete without a photograph of this individual may impact the findings. The use of a hypothetical athlete was derived from Cunningham and Regan (2012) who previously utilized this format. The decision to withhold a picture from the packet may have impacted respondents' views of the athlete. Without a picture or identified racial identity, the respondent was able to visualize any male individual in track. This may have impacted the results. However, this study did not investigate the impact of race or physical appearance, but the impact of high/low and risky/safe activism. Additionally, the focus groups and study sample were not similar. The focus group was surveyed using a convenience sample consisting of a mostly male and Black sample with an average age of 20 years old. The study sample consisted of mostly White males with an average age of 37 . This limitation was addressed by the researchers, who utilized manipulation checks to ensure the focus groups and study sample agreed on what constituted high and low effort of activism and safe and risky forms of activism. An additional limitation is using only brand familiarity as a covariate. Research suggests there are multiple influencers of the celebrity endorser that impact the effectiveness of the endorsement (Kim \& $\mathrm{Na}, 2007)$. Brand familiarity was chosen due to its use in Loheniess and Hill (2014), which was used as a guide for the current study.
Future research should investigate the athlete activist and the impact activism has within the sport industry. The year of 2016 saw a stark resurgence in athlete activism that was silenced in the 1990s (Agyemang, 2011). Athletes, now more than ever, feel empowered to stand up against the social injustices in this world. As such, the sport industry is being impacted from marketing and social standpoints. From a marketing standpoint, LeBron James and several National Basketball Association (NBA) players wore I Can't Breathe shirts during pre-game warm-up shirts in 2014. Despite the players breaking the rules by wearing non-Adidas shirts for warmups, NBA commissioner Adam Silver did not fine the players (Boren, 2014). While this move may seem admirable by Silver, it could have a detrimental impact on the sponsorship value between Adidas and the NBA. Perhaps, however, the move is increasing the value, as the goodwill towards the NBA and Adidas for not punishing the players may be off setting the loss in value from the sponsorship. From a social standpoint, society's views and behaviors towards athletes using the field for political protest could be examined. There is a widely held belief that sport is neutral and exists without the political realms of sport (Sage, 1998). However, with prominent athletes like LeBron James, Colin Kaepernick, Megan Rapinoe, Serena Williams, and many more, the notion that sport is neutral to the political realm simply may not be true. As researchers continue to investigate the impact and effects of activism within athletics, a clearer picture can be presented for organizations, athletes, and potential sponsors.

\section{References}

Agyemang, K. J. (2011). Black male athlete activism and the link to Michael Jordan: A transformational leadership and social cognitive theory analysis. International Review for the Sociology of Sport, 47(4), 433-445.

Agyemang, K. J., Singer, J. N., \& DeLorme, J. (2010). An exploratory study of Black male college athletes' perceptions on race and athlete activism. International Review for the Sociology of Sport, 45(4), 419-435.

Ajzen, I. (1985). From intentions to actions: A theory of planned behavior. In J. Kuhl \& J. Beckman (Eds.), Action-control: From cognition to behavior (pp.11-39). Heidelberg, Germany: Springer.

Alba, J. W., \& Hutchinson, J. W. (1987). Dimensions of consumer expertise. The Journal of Consumer Research, 13(4), 411-454.

Bauer, H. H., Stokburger-Sauer, N. E., \& Exler, S. (2008). Brand image and fan loyalty in professional team sport: A refined model and empirical assessment. Journal of Sport Management, 22, 205-226.

Bayat, A. (2005). Islamism and social movement theory. Third World Quarterly, 26(6), 891-908.

Biehal, G. J., \& Shinin, D. A. (2007). The influence of corporate messages on the product portfolio. Journal of Marketing, 71, $12-25$. 
Boren, C. (2014, December 9). NBA won't fine LeBron James, Derrick Rose, and others for 'I can't breathe' protests. The Washington Post. Retrieved from https://www.washingtonpost.com/news/early-lead/wp/2014/12/09/nba-wont-finelebron-james-derrick-rose-and-others-for-i-cant-breathe-protests/?utm_term $=.184 \mathrm{a} 5005 \mathrm{c} 3 \mathrm{c} 9$

Breech, J. (2016, September 12). Here are the 11 player who joined Colin Kaepernick's protest in week 1. CBS Sports. Retrieved from http://www.cbssports.com/nfl/news/here-are-the-11players-who-joined-colin-kaepernicks-protest-in-week-1/

Buhrmester, M., Kwang, T., \& Gosling, S. D. (2011). Amazon's Mechanical Turk: A new source of inexpensive, yet high-quality, data? Perspectives of Psychological Science, 6(1), 3-5.

Carrillat, F. A., Laffert, B. A., \& Harris, E. G. (2005). Investigating sponsorship effectiveness: Do less familiar brands have an advantages over more familiar brands in singled and multiple sponsorship agreements? Journal of Brand Management, 13(1), $50-64$.

Christensen, H. S. (2012). Simply slacktivism? Internet participation in Finland. JeDEM-eJournal of eDemocracy and Open Government, 4(1), 1-23.

Clayton, A. (2016, August 28). 49ers QB Colin Kaepernick sits out anthem, rages vs. racism. New York Dailey News. Retrieved from http://www.nydailynews.com/sports/football/49ers-qb-colin-kaepernick-sits-national-anthemarticle-1.2768072

Creswell, J. W. (2014). Research design: Qualitative, quantitative and mixed methods approaches (4th ed.). Thousand Oaks, CA: Sage Publications, Inc.

Crabtree, C. (2016, September 15). Brandon Marshall picks up new endorsement after losing two following anthem kneel. NBC Sports. Retrieved from http://profootballtalk.nbcsports. com/2016/09/15/brandon-marshall-picks-up-new-endorsement-after-losing-two-following-anthem-kneel/

Crompton, J. L. (2004). Conceptualization and alternate operationalizations of the measurement of sponsorship effectiveness in sport. Leisure Studies, 23(3), 267-281.

Cunningham, G. B., Fink, J. S., \& Kenix, L. J. (2007). Choosing an endorser for a women's sporting event: The interaction of attractiveness and expertise. Sex Roles, 58, 371-378.

Cunningham, G. B., \& Regan, M. R. (2012). Political activism, racial identity and the commercial endorsement of athletes. International Review for the Sociology of Sport, 47, 657-669.

Cunningham, N., \& Bright, L. F. (2012). The tweet is in your court: Measuring attitude towards athlete endorsements in social media. International Journal of Integrated Marketing Communications, 4(2), 73-87.

Dees, W., Bennett, G., \& Villegas, J. (2008). Measuring the effectiveness of sponsorship of an elite intercollegiate football program. Sport Marketing Quarterly, 17(2), 79-89.

Erdogan, B. Z. (1999). Celebrity endorsement: A literature review. Journal of Marketing Management, 15, 291-314.

Fink, J. S., Cunningham, G. B., \& Kensicki, L. J. (2004). Using athletes as endorsers to sell women's sport: Attractiveness vs. expertise. Journal of Sport Management 18(4), 350-367.

Garcia, A., \& Dotson, K. (2016, September 9) Denver Broncos' Brandon Marshall gets dropped by sponsor for anthem protest. CNN Money. Retrieved from http://money.cnn.com/2016/09/09/news/ brandon-marshall-national-anthem-protest-aafcu/

Gladden, J. M., \& Funk, D. C. (2001). Understanding brand loyalty in professional sport: Examining the link between brand associations and brand loyalty. International Journal of Sports Marketing \& Sponsorship, 3, 67-91.
Goldsmith, R. E., Lafferty, B. A., \& Newell, S. J. (2000). The impact of corporate credibility and celebrity credibility on consumer reaction to advertisements and brands. Journal of Advertising, 29(3), 43-54.

Gwinner, K. P., \& Eaton, J. (1999). Building brand image through event sponsorship: The role of image transfer. Journal of Advertising, 28(4), 47-57.

Heitner, D. (2016, September 7). Colin Kaepernick tops jersey sales in NFL. Forbes. Retrieved from http:// www.forbes.com/sites/darrenheitner/2016/09/07/ colin-kaepernick-tops-jersey-sales-in-nfl/\#372a17cb39a1

Kamins, M. A. (1990). An investigating into the 'Match-up' hypothesis in celebrity advertising: When beauty may be only skin deep. Journal of Advertising, 19(1), 4-13.

Kaufman, P. (2008). Boos, bans and other backlash: The consequences of being an activist athlete. Humanity and Society, 32, 215-237.

Kaufman, P., \& Wolff, E. (2010). Playing and protesting: Sport as a vehicle for social change. Journal of Sport and Social Issues, 34(2), 154-175.

Keller, L. K. (1993). Conceptualizing, measuring, and managing customer-based brand equity. Journal of Marketing, 57(1), $1-22$.

Kent, R. J., \& Allen, C. T. (1994). Competitive interference effects in consumer memory for advertising: The role of brand familiarity. Journal of Marketing, 58(3), 97-105.

Kim, Y., \& Na, J. (2007). Effects of celebrity athlete endorsement on attitude towards the product: The role of credibility, attractiveness, and the concept of congruence. International Journal of Sports Marketing \& Sponsorship, 8(4), 310-313.

Kristofferson, K., White, K., \& Peloa, J. (2014). The nature of slacktivism: How the social observability of an initial act of token support affects subsequent prosocial action. Journal of Consumer Research, 40(6), 1149-1166.

Kwon, H. H., Trail, G., \& James, J. D. (2007). The mediating role of perceived value: Team identification and purchase intention of team-licensed apparel. Journal of Sport Management, 21, $540-554$.

Lim, M. (2013). Many clicks but little sticks: Social media activism in Indonesia. Journal of Contemporary Asia, 43(4), 636-657.

Lohneiss, A., \& Hill, B. (2014). The impact of processing athlete transgressions on brand image and purchase intent. European Sport Management Quarterly, 14(2), 171-193.

Martínez, E., \& Pina, J. M. (2009). Modeling the brand extensions' influence on brand image. Journal of Business Research, 62, $50-60$.

Mason, W., \& Suri, S. (2012). Conducting behavioral research on Amazon's Mechanical Turk. Behavior Research Methods, 44(1), 1-23.

McCracken, G. (1989). Who is the celebrity endorser? Cultural foundations of the endorsement process. Journal of Consumer Research, 16(3), 310-321.

McManus, J. (2015, December 23). Cam Newton's passion for helping kids is real. ESPN. Retrieved from http://www.espn.com/nfl/story/_/id/14426632/ cam-newton-passion-helping-kids-endorsers-buying-nfl

Murray, D., \& Price, B. (2012). When sports stars go off the rails: How gender and involvement influence the negative publicity of sport endorsers. International Journal of Business Research, 12(2), 84-93.

O’Donnell, R. (2016, August 4). Carmelo Anthony's activism gets the global platform it deserves thanks to team USA. SB Nation. Retrieved from http://www.sbnation.com/2016/8/4/12341712/ carmelo-anthony-activism-team-usa-basketball-social-change 
Ohanian, R. (1990). Construction and validation of a scale to measure celebrity endorsers' perceived expertise, trustworthiness, and attractiveness. Journal of Advertising, 19(3), 39-52.

Pleasance, C. (2016, August 28). 'You should never play in the NFL again. Move to Canada': 49ers fans burn Kaepernick jerseys to the national anthem after the $\$ 114$ million sport start refused to stand 'to protest Black oppression.' Daily Mail. Retrieved from http://www.dailymail.co.uk/news/article-3762239/Younever-play-NFL-Canada-49ers-fans-burn-Kaepernick-jerseysnational-anthem-114million-sport-star-refused-stand-protestBlack-oppression.html

Presley, R. G., Shreffler, M. B., Hancock, M. G., \& Schmidt, S. H. (2016). Issues \& Ethics in sport: A practical guide for sport managers. Dubuque, IA: Kendall Hunt.

Robinson, W. (2016, August 31). 'F*** that guy': Anonymous NFL executives reveal how the league leadership all 'hate Colin Kaepernick, call him a traitor and believe he is unlikely to play pro ball again.' Daily Mail. Retrieved from http://www. dailymail.co.uk/news/article-3768174/NFL-executives-hateColin-Kaepernick-call-traitor-believe-unlikely-play-pro-ballagain.html

Ross, S. D., James, J. D., \& Vargas P. (2006). Development of a scale to measure team brand association in professional sport. Journal of Sport Management, 20, 260-279.

Sage, G. H. (1998). Power and ideology in American sport: A critical perspective (2nd ed.). Champaign, IL: Human Kinetics Press.

Sanderson, J., Frederick, E., \& Stocz, M. (2016). When athlete activism clashes with group values: Social identity threat management via social media. Mass Communication and Society, 19(3), 301-322.
Schilken, C. (2016, August 31). Kareem Abdul-Jabbar: Colin Kaepernick's protest is 'highly patriotic'. Los Angeles Times. Retrieved from http://www.latimes.com/sports/nfl/la-sp-colin-kaepernick-alex-boone-20160829-snap-story.html

Schmittel, A., \& Sanderson, J. (2015). Talking about Trayvon in 140 characters: Exploring NFL players' tweets about the George Zimmerman verdict. Journal of Sport and Social Issues, 39(4), 332-345.

Seno, D., \& Lukas, B. A. (2007). The equity effect of product endorsement by celebrities. European Journal of Marketing, 41(1/2), 121-134.

Silvera, D. H., \& Austad, B. (2004). Factors predicting the effectiveness of celebrity endorsement advertisements. European Journal of Marketing, 38(11/12), 1509-1526.

Spears, N., \& Singh, S. N. (2004). Measuring attitude toward the brand and purchase intentions. Journal of Current Issues and Research in Advertising, 26(2), 53-66.

Villanueva, R. (2016, September 13). Broncos' Brandon Marshall loses another sponsor, will continue to kneel during anthem. USA Today. Retrieved from http://www.usatoday.com/story/ sports/nfl/broncos/2016/09/12/brandon-marshall-centurylink-sponsor-national-anthem-kneeling/90277042/

Weber, S. (2016, June 29). Top 100 highest-paid athlete endorsers of 2016. Opendorse.com. Retrieved from http://opendorse. com/blog/2016-highest-paid-athlete-endorsers/

Wilder, C. (2016, August 30). Donald Trump says Colin Kaepernick should find a new country. The New York Times. Retrieved from http://ftw.usatoday.com/2016/08/ donald-trump-colin-kaepernick-new-country-national-anthem-protest-response

\section{Appendix A}

\section{Survey Instrument}

\section{Nike's sponsor search}

Nike, in attempting to strengthen the brand image of its high performance athletic shoe, is seeking to add a new spokesperson. To do so, it has gathered information about various nationally-recognized track and field athletes. This includes their accomplishments, personal information, and the community engagement in which the athletes are involved. Please review the material provided on the following pages and, after doing so, provide your assessment of your attitudes towards Nike.

Regarding the organization Nike, are you:

$\begin{array}{lrllllr}1 & 2 & 3 & 4 & 5 & 6 & 7 \\ \text { Unfamiliar } & & & & \text { Familiar }\end{array}$

Unfamiliar

Inexperienced

$\begin{array}{lrr}1 & 2 & 3 \\ \text { Unknowledgeable }\end{array}$

4

5

$5 \quad 6 \quad 7$

Knowledgeable

Please rate your views of the organization Nike:

$\begin{array}{lllllll}1 & 2 & 3 & 4 & 5 & 6 & 7\end{array}$

Not good

$\begin{array}{lclllrr}1 & 2 & 3 & 4 & 5 & 6 & 7 \\ \text { Low quality } & & & & \text { High quality }\end{array}$

$\begin{array}{llllll}1 & 2 & 3 & 4 & 5 & 6\end{array}$

7

Inferior

Superior

$\begin{array}{lcllllr}1 & 2 & 3 & 4 & 5 & 6 & 7 \\ \text { Not beneficial } & & & & & \text { Beneficial }\end{array}$

$\begin{array}{lllllll}1 & 2 & 3 & 4 & 5 & 6 & 7\end{array}$

Unfavorable

Favorable

$\begin{array}{lrrrrrr}1 & 2 & 3 & 4 & 5 & 6 & 7 \\ \text { Negative } & & & & & \text { Positive }\end{array}$


$\begin{array}{llllllll}1 & 2 & 3 & 4 & 5 & 6 & 7\end{array}$

Strongly Dislike

Please rate your views towards Nike's athletic shoes

I would purchase Nike shoes:

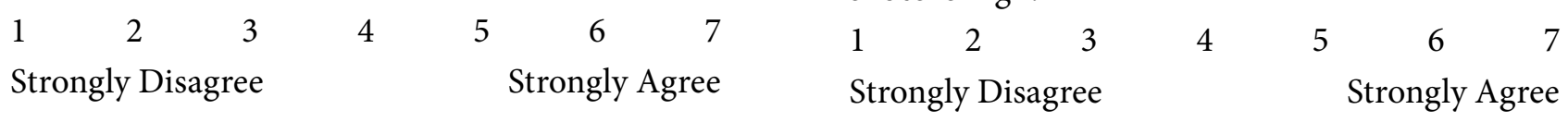

Athlete: Charles Smith

Sport: Track and Field

Event: $800 \mathrm{~m}$ distance

Accomplishments:

-1st Place- 2014 NCAA Outdoor 800m

-3rd place- 2014 USA Outdoor Championships

-5th Place- 2014 World Outdoor Championships

-3 time NCAA All-American
I would consider buying Nike shoes:

$\begin{array}{llllllll}1 & 2 & 3 & 4 & 5 & 6 & 7\end{array}$

Strongly Disagree Strongly Agree shoes is high:
The probability that I would consider buying Nike

\section{Community Engagement:}

Charles Smith spends considerable time posting tweets for Black Lives Matter. This is a non-profit organization with the primary aim of advancing the understanding of the causes, consequences, and prevention of racial inequality.

People generally support the cause for which the athlete volunteers his time:

$\begin{array}{lllllll}1 & 2 & 3 & 4 & 5 & 6 & 7\end{array}$

Strongly Disagree Strongly Agree

The athlete gave a high level of effort towards combatting the social cause:

$\begin{array}{lllllll}1 & 2 & 3 & 4 & 5 & 6 & 7\end{array}$

Strongly Disagree Strongly Agree

Please rate your views on the organization Nike with Charles Smith endorsing its product:

$\begin{array}{llllllll}1 & 2 & 3 & 4 & 5 & 6 & 7\end{array}$

Not good

Good

$\begin{array}{lllllll}1 & 2 & 3 & 4 & 5 & 6 & 7\end{array}$

Low quality

High quality

$\begin{array}{lrlrrrr}1 & 2 & 3 & 4 & 5 & 6 & 7 \\ \text { Inferior } & & & & \text { Superior }\end{array}$

$\begin{array}{lllllll}1 & 2 & 3 & 4 & 5 & 6 & 7\end{array}$

Not beneficial

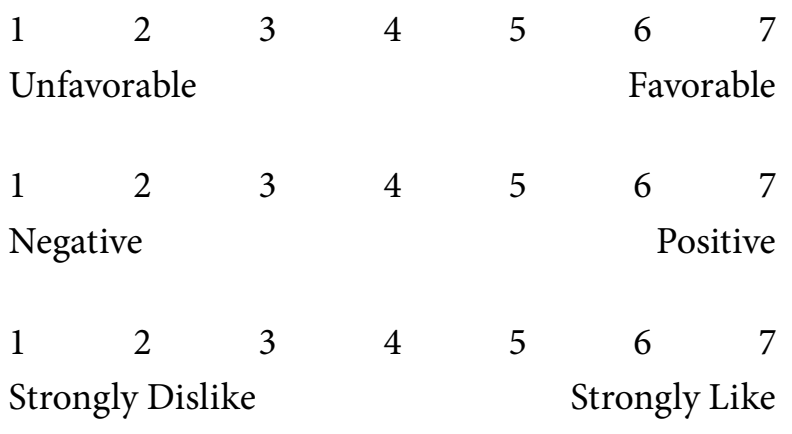

Please rate your views towards Nike's athletic shoes.

I would purchase Nike shoes:

$\begin{array}{lllllll}1 & 2 & 3 & 4 & 5 & 6 & 7\end{array}$

Strongly Dislike Strongly Like

I would consider buying Nike shoes:

$\begin{array}{llllllll}1 & 2 & 3 & 4 & 5 & 6 & 7\end{array}$

Strongly Dislike Strongly Like

The probability that I would consider buying Nike shoes is high:

$\begin{array}{lrrrrrr}1 & 2 & 3 & 4 & 5 & 6 & 7 \\ \text { Strongly Dislike } & & & & & \text { Strongly Like }\end{array}$

